\title{
Analisis Investasi Syariah Sukuk Negara: Komparasi Sukuk Ritel dan Sukuk Tabungan
}

\author{
Ai Cucu Raksawati ${ }^{1 *}$, Nugraha ${ }^{2)}$, Maya Sari ${ }^{3)}$ \\ $\left.1^{*}, 2,3\right)$ Universitas Pendidikan Indonesia (Sekolah Pasacarjana) \\ Jalan Dr. Setiabudhi No. 229 Kota Bandung, Provinsi Jawa Barat, 40154 \\ E-mail: aicucu@upi.edu ${ }^{1 *}$
}

\begin{abstract}
ABSTRAK
Penelitian ini mengkaji Sukuk Negara yang terdiri dari Sukuk Retail (SR) dan Sukuk Tabungan (ST) yang merupakan bagian dari Surat Berharga Syariah Negara (SBSN). Dalam investasi Sukuk, selain memperoleh imbalan, masyarakat juga turut serta membantu pembangunan Dalam Negeri. Tujuan dari peneitian ini untuk menganalisis imbalan/kupon perolehan dari investasi SR maupun ST dan menilai kecenderungan investasi syariah dalam Sukuk Negara masyarakat Indonesia. SR sudah terbit sejak Februari 2009, sedangkan ST baru terbit pada 2016. nilai outstanding SR pun lebih besar daripada ST. Analisis data dilakukan secara kualitatif dan perhitungan data sekunder untuk komparasi, diperoleh melalui laman resmi Ditjen Pengelolaan Pembiayaan dan Risiko. Selain perbedaan jatuh tempo, antara SR dan ST berbeda dalam penentuan besarnya imbalan serta tradability nya. Dari hasil penelitian diketahui bahwa dalam menentukan SR ataupun ST tergantung kondisi fundamental suatu negara. Jika kondisi negara relatif stabil untuk 2-3 tahun kedepan, maka investasi pada Sukuk Tabungan relatif menguntungkan. Namun jika situasi fundamental negara relatif fluktuatif, terdapat berbagai ketidakpastian, maka investasi pada Sukuk Ritel adalah pilihan investasi yang lebih baik.
\end{abstract}

Kata Kunci: Sukuk Ritel, Sukuk Tabungan, Sukuk Negara, Investasi Syariah

\begin{abstract}
This study examines Sovereign Sukuk which consists of Sukuk Retail (SR) and Sukuk Tabungan (ST) which are part of the Surat Berharga Syariah Negara (SBSN). Benefit Investing in Sukuk, not only earning returns, but also participates in helping country development. The purpose of this research is to analyze the returns / coupons obtained from SR and ST investments and to assess the trend of sharia investment in Sovereign Sukuk for the Indonesian people. SR has been published since February 2009, while ST has been published in 2016. The outstanding value of SR is also greater than ST. Data analysis was carried out qualitatively and secondary data calculations for comparison were obtained through the official website of the Directorate General of Financing and Risk Management. Apart from the difference in maturity date, the SR and ST differ in determining the amount of the returns and its tradability. From the research results, it is known that determining SR or $S T$ depends on the fundamental conditions of a country. If the country's conditions are relatively stable for 2-3 years later, so investment in Savings Sukuk will be relatively profitable. However, if the country's fundamentals are relatively volatile and there are various uncertainties, then investing in Retail Sukuk is a better investment option.
\end{abstract}

Keywords: Sukuk Ritel, Sukuk Tabungan, Sovereign Sukuk, Sharia Investment 


\section{PENDAHULUAN}

Indonesia sudah lama mengenal obligasi sebagai salah satu instrumen investasi. Oktober 2002 merupakan titik awal terbitnya obligasi syariah yang dipelopori Indosat. Pada saat itu terjadi peningkatan permintaan obligasi syariah indosat sebanyak dua kali, dikarenakan antusiasme masyarakat atas obligasi syariah. Tentunya tingginya jumlah penduduk muslim di Indonesia (87\% di tahun 2020) menjadikan Sukuk (yang dulu dikenal obligasi syariah) sebagai alternatif investasi yang sesuai syariah. Sukuk berbeda dengan obligasi. Sukuk bukanlah surat utang, melainkan surat berharga syariah berupa sertifikat atau bukti kepemilikan atas aset (dasar Sukuk). Adanya perbedaan fundamental antara penerbitan Sukuk Syariah serta struktur obligasi konvensional ialah terkait persyaratan aset berwujud yang mendasari setiap penerbitan Sukuk.

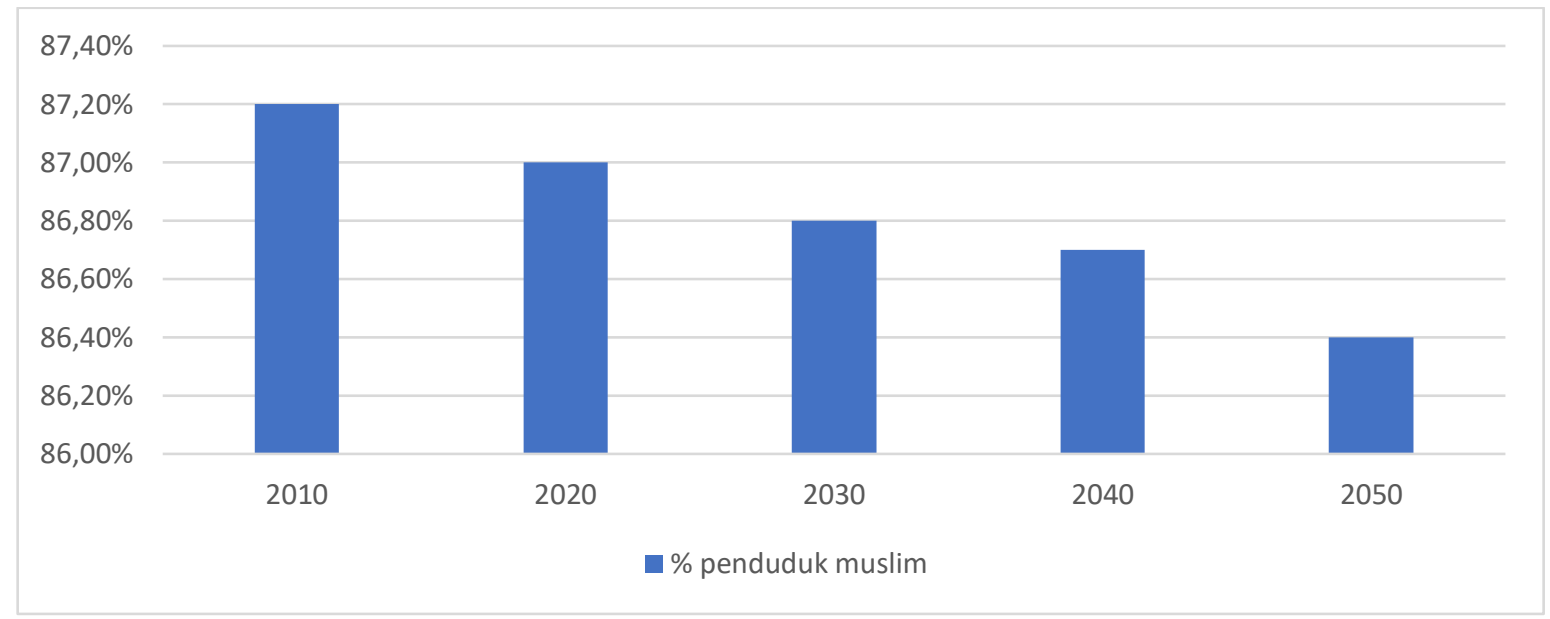

Gambar 1. Proyeksi Prosentase Populasi Muslim di Indonesia 2010-2050

Sumber: http://www.globalreligiousfutures.org/, diolah

Melihat fenomena besarnya potensi perkembangan Sukuk di Indonesia, dan menyimpulkan banyak Investor muslim menjadikan sukuk sebagai salah satu alternatif instrumen investasi (Handayani \& Surachman, 2017; Muhammad et al., 2019). Sukuk dianggap pilihan yang lebih baik karena penerbitannya didasarkan adanya unsur Ijarah dalam investasi, berbagi resiko dan keterlibaran aset (proyek-riil) (Wafa, 2010). Walaupun Sukuk merupakan investasi yang paling aman karena risiko dari Sukuk, dinilai paling kecil dibandingkan investasi lainnya dan investasi Sukuk mampu meningkatkan nasionalisme. Namun seorang calon investor yang rasional, tentu perlu menganalisis faktor fundamental maupun teknikal untuk memutuskan apakah akan memilih berinvestasi pada Sukuk Tabungan atau Sukuk Ritel. Terdapat perbedaan mendasar antar Sukuk Negara (Sukuk Ritel dengan 
Sukuk Tabungan). Maka penting untuk menganalisis sejauh mana Sukuk negara, diantara Sukuk Ritel maupun Sukuk Tabungan yang dinilai paling menguntungkan berdasarkan analisis empiris.

Beberapa peneliti berfokus pada dampak kondisi makroekonomi terhadap Sukuk (Ahmad et al., 2012), serta permintaan sukuk nya (Muhammad et al., 2019; Wafa, 2010). Faktor yang mempengaruhi peringkat sukuk (Sudaryanti et al., 2011), membandingkan sukuk dengan obligasi konvensional (Godlewski et al., 2013; Purnamawati, n.d.; Ramasamy et al., 2011). Maka disana terdapat keterbatasan studi tentang Sukuk. Masih jarang penelitian di Indonesia, mengungkapkan secara detail informasi historis return nya, sehingga bisa memberikan gambaran prospek Sukuk Ritel dan Sukuk Tabungan di masa mendatang. Oleh karena itu, dalam penelitian ini akan membahas lebih mendalam terkait Sukuk dalam sudut pandang return historis nya. Tujuan dari penelitian ini adalah memberikan informasi pada masyarakat, seperti apa pola return yang diperoleh oleh Sukuk Ritel dan Sukuk Tabungan didasarkan pada data historis, menilai kecenderungan para investor Sukuk di Indonesia serta menilai investasi mana yang lebih menguntungkan.

\section{METODE PENELITIAN}

Penelitian dilakukan dengan menggunakan analsis kualitatif. Data yang diperoleh merupakan data sekunder yang diperoleh dari DJPPR. Data yang dianalisis adalah data Sukuk negara (Sukuk Retail dengan Sukuk Tabungan). Menganalisis return berdasarkan data historis menjadi penting terkait kesempurnaan informasi. Suatu pasar dikatakan efisien ketika berkenaan dengan kumpulan informasi (Jensen, 1978). Untuk dapat menggeneralisasi hasil penelitian, maka dilakukan pembatasan objek penelitian hanya terkait ST dan SR yang dikeluarkan di tahun 2016, 2017 dan 2018 dan telah berjalan selama dua tahun. yaitu ST001 dan ST002 serta SR008, SR009 dan SR010. Dan penulis mencoba menganalisis perolehan imbalan/kupon

Tabel I. Objek Penelitian

\begin{tabular}{ll}
\hline & Tanggal Penerbitan \\
\hline SR008 & 10 March 2016 \\
SR009 & 22 March 2017 \\
SR010 & 21 March 2018 \\
ST001 & 07 September 2016 \\
ST002 & 29 November 2018 \\
\hline
\end{tabular}


Mandiri sekuritas dalam mandirisekuritas.co.id merekomendasikan besaran investasi ideal sebesar Rp. 10.000.000. Maka dalam penelitian ini, penulis mengasumsikan besaran investasi Sukuk sebesar Rp. 10.000.000. Adapun perhitungan kuponnya, seperti yang terlihat pada Tabel 5, 6 dan 7

\section{Tabel 2. Besaran Kupon dalam Akumulasi Dua Tahun (SR 008, SR 009 dan SR 010)}

\begin{tabular}{|c|c|c|c|c|c|}
\hline SR 008 & Nilai & SR 009 & Nilai & SR 010 & Nilai \\
\hline $\begin{array}{l}\text { Imbalan per tahun } \\
(8,3 \%)\end{array}$ & 830.000 & $\begin{array}{l}\text { Imbalan per tahun } \\
(6,9 \%)\end{array}$ & 690.000 & $\begin{array}{l}\text { Imbalan per tahun } \\
(5,9 \%)\end{array}$ & 590.000 \\
\hline Imbalan per bulan & 69.167 & Imbalan per bulan & 57.500 & Imbalan per bulan & 49.167 \\
\hline Pajak/bulan 15\% & 10.375 & Pajak/bulan 15\% & 8.625 & Pajak/bulan 15\% & 7.375 \\
\hline imbala & $\begin{array}{r}58.792 \\
1.411 .00\end{array}$ & imbalan bersih/bulan & $\begin{array}{r}48.875 \\
1.173 .00\end{array}$ & imbalan bersih/bulan & $\begin{array}{r}41.792 \\
1.003 .00\end{array}$ \\
\hline Selama 2 tahun & 0 & Selama 2 tahun & 0 & Selama 2 tahun & 0 \\
\hline
\end{tabular}

Dikarenakan Imbalan per tahun untuk SR 008 lebih tinggi daripada SR 009 dan SR 010, maka perolehan imbalan setelah dikalkulasikan selama 2 tahun pun, nilai nya, paling besar.

Tabel 3. Besaran Kupon dalam Akumulasi Dua Tahun (ST 001)

\begin{tabular}{lr}
\hline \multicolumn{1}{c}{ ST 001 } & Nilai \\
\hline Imbalan per tahun $(6,9 \%)$ & 690.000 \\
Imbalan per bulan & 57.500 \\
Pajak/bulan 15\% & 8.625 \\
imbalan bersih/bulan & 48.875 \\
Selama 2 tahun & 1.173 .000 \\
\hline
\end{tabular}

Tabel 4. Besaran Kupon dalam Akumulasi Dua Tahun (ST 002)

\begin{tabular}{|c|c|c|c|c|c|}
\hline \multicolumn{6}{|c|}{ ST 002} \\
\hline Imbalan per tahun $(8,3 \%)$ & 830.000 & Imbalan per tahun $(8,55 \%)$ & 855.000 & Imbalan per tahun $(8,3 \%)$ & 830.000 \\
\hline Imbalan per bulan & 69.167 & Imbalan per bulan & 71.250 & Imbalan per bulan & 69.167 \\
\hline Pajak/bulan $15 \%$ & 10.375 & Pajak/bulan $15 \%$ & 10.688 & Pajak/bulan $15 \%$ & 10.375 \\
\hline imbalan bersih/bulan & 58.792 & imbalan bersih/bulan & 60.563 & imbalan bersih/bulan & 58.792 \\
\hline Selama Des 2018-Feb 2019 & 176.375 & Selama Mar 2019-Agst 2019 & 363.375 & Selama Sep 2019=Nov 2019 & 176.375 \\
\hline Imbalan per tahun $(8,55 \%)$ & 855.000 & Imbalan per tahun $(8,05 \%)$ & 805.000 & Imbalan per tahun $(8,3 \%)$ & 830.000 \\
\hline Imbalan per bulan & 71.250 & Imbalan per bulan & 67.083 & Imbalan per bulan & 69.167 \\
\hline Pajak/bulan $15 \%$ & 10.688 & Pajak/bulan $15 \%$ & 10.063 & Pajak/bulan $15 \%$ & 10.375 \\
\hline imbalan bersih/bulan & 60.563 & imbalan bersih/bulan & 57.021 & imbalan bersih/bulan & 58.792 \\
\hline Imbalan per tahun $(8,55 \%)$ & 855.000 & & & & \\
\hline Imbalan per bulan & 71.250 & & & & \\
\hline Pajak/bulan $15 \%$ & 10.688 & & & & \\
\hline imbalan bersih/bulan & 60.563 & & & & \\
\hline Selama okt 2020-Nov 2020 & 121.125 & Selama 2 Tahun & 1.425 .167 & & \\
\hline
\end{tabular}




\section{HASIL DAN PEMBAHASAN}

Sudarsono (2008) bahwa Sukuk berasal dari kata sakk yang berarti dokumen atau lembaran kontrak. Dalam POJK Nomor 18/POJK.04/2015, Sukuk atau Surat Berharga Syariah Negara (SBSN) merupakan efek syariah sertifikat atau bukti kepemilikan atas aset, baik dalam mata uang rupiah maupun valuta asing. Ketentuan mengenai SBSN diatur dalam Undang Undang Nomor 19 Tahun 2008 tentang Surat Berharga Syariah Negara.Investasi Sukuk mewakili kelas sekuritas yang berbeda yang diterbitkan oleh entitas berdaulat (pemerintah) dan korporasi (Godlewski et al., 2013).

Karena dikeluarkan oleh pemerintah, Sukuk Negara (Sovereign Sukuk) adalah salah satu pembiayaan yang inovatif dalam menciptakan pengeluaran yang produktif, yang dapat dijadikan sebagai sumber pembiayaan potensial untuk infrastruktur (Handayani \& Surachman, 2017). Fokus pada harga dan karakteristik risiko merupakan inti dari inovasi dalam suatu investasi (Wilson, 2008).

Dari aspek investor, Sukuk Negara bisa dijadikan referensi investasi yang potensial. Dengan pajak yang relatif lebih ringan, jika dibandingkan dengan deposito, adanya return bulanan dan yang paling penting, adanya jaminan pemerintah, menjadikan Sukuk Ritel banyak digemari di Indonesia. Nominal pemesanan yang relatif terjangkau menjadi daya tarik tersendiri bahi Sukuk Negara. Namun seringkali orang menjadi bingung, dihadapkan atas pilihan sukuk ritel atau sukuk tabungan Pada Tabel 2 terlihat perbedaan Sukuk Ritel (SR) dan Sukuk Tabungan (ST).

Return dari Sukuk Ritel, nilainya tetap (fix) dikarenakan akad dalam Sukuk Ritel adalah ijarah (sewa). Investasi Sukuk pun dinilai aman karena dilindungi dua undang-undang yaitu SBSN dan APBN.

Segala hal yang menghasilkan bunga, atau riba, tentu saja dilarang berdasarkan hukum. Sukuk Syariah sering dikaitkan dengan obligasi. Wilson (2007), investor obligasi konvensional jarang tertarik untuk mengetahui apa yang dibiayai melalui penerbitan obligasi (dikhawatirkan untuk pembiayaan industri yang dianggap haram) dan Inilah yang tidak boleh dilakukan oleh investor muslim. 
Tabel 5. Perbandingan Sukuk Ritel dengan Produk Investasi Lainnya

\begin{tabular}{|c|c|c|c|c|}
\hline & Sukuk Ritel & Deposito & Reksadana & Saham \\
\hline Return/imbalan & $\begin{array}{c}\text { Imbalan } \\
\text { setiap bulan }\end{array}$ & Bunga & $\begin{array}{c}\text { Kenaikan aktiva } \\
\text { bersih }\end{array}$ & Dividen \\
\hline $\begin{array}{l}\text { Pasar sekunder } \\
\text { dan potensi } \\
\text { capital gain }\end{array}$ & Ada & Tidak ada & Ada & Ada \\
\hline $\begin{array}{c}\text { Masa Jatuh } \\
\text { tempo }\end{array}$ & Ada & Ada & Ada & Tidak ada \\
\hline $\begin{array}{c}\text { Jaminan } \\
\text { Pemerintah }\end{array}$ & Ada $100 \%$ & $\begin{array}{c}\text { Maksimal } 2 \\
\text { Miliar }\end{array}$ & Tidak ada & Tidak ada \\
\hline $\begin{array}{l}\text { Pajak terhadap } \\
\text { imbalan }\end{array}$ & $15 \%$ Final & $20 \%$ Final & $\begin{array}{l}\text { Khusus untuk } \\
\text { investasi } \\
\text { reksadana pada } \\
\text { obligasi/sukuk } \\
\text { dikenakan pajak } \\
\text { final 5\% dari } \\
\text { imbalan }\end{array}$ & $\begin{array}{l}10 \% \text { dari } \\
\text { Final tas } \\
\text { dividen }\end{array}$ \\
\hline
\end{tabular}

Sumber: https://www.djppr.kemenkeu.go.id/

Dahulu, Sukuk sering dikaitkan dengan obligasi. Bahkan menyebut Sukuk merupakan istilah lain dari obligasi syariah. Sukuk sangatlah berbeda dengan obligasi. Perbedaan yang mengemuka antara sukuk dengan obligasi konvensional pada underlying asset yang digunakan (Godlewski et al., 2013; Sudarsono, 2008; Wafa, 2010). Di dalam sukuk, underlying asset dibutuhkan sebagai jaminan bahwa penerbitan sukuk didasarkan nilai yang sama dengan aset yang tersedia. Oleh karenanya, aset harus memiliki nilai ekonomis, baik berupa aset berwujud atau tidak berwujud, termasuk proyek yang akan atau sedang dibangun (Wafa 2010) bahwa underlying asset mendasari pembiayaan instrument sukuk sehingga berdampak tidak mengandung unsur spekulasi dan merupakan pembiayaan aktivitas ekonomi riil.

Adapun fungsi underlying asset tersebut adalah: (i) untuk menghindari riba, (ii) sebagai prasyarat untuk dapat diperdagangkan nya sukuk di pasar sekunder, dan (iii) akan menentukan jenis struktur sukuk.

Investor di Sukuk Negara, selain menghasilkan keuntungan dari sejumlah uang yang diinvestasikan, juga membantu pembangunan infrastruktur suatu negara. Investor bisa memilih antara Sukuk Ritel (SR) dengan Sukuk Tabungan (ST). SR001 first issue date pada 25 Februari 2009 dengan maturity date 25 Februati 2012. Sedangkan ST001 first issue date pada 7 September 2016 dengan maturity date 7 Januari 2018. Imbalan kedua Sukuk Negara memiliki besaran yang berbeda. Perbedaan terjadi karena SR menetapkan Imbal Fix (tetap), sedangan imbal ST Berubah tetapi tetap adanya minimal pembayaran (floating with floor). 
floating with floor ini berarti kupon/imbalan bisa meningkat atau bisa turun, tapi tidak akan dibawah imbalan/kupon yang sudah ditetapkan diawal

Kita tahu, bahwa dalam teori mikroekonomi, (N. Gregory, 2019) bahwa harga merupakan salah satu komponen yang mempengaruhi jumlah permintaan. Dalam pengambilan keputusan investasi, return menjadi alasan utama orang dalam berinvestasi (Tandelin, 2017). Banyak penelitian yang meneliti faktor yang mempengaruhi Sukuk, Wafa (2010) secara bersama-sama faktor independen yang terdiri dari harga sukuk negara ritel, harga obligasi ritel, tingkat bagi hasil deposito bank syariah, dan tingkat suku bunga mempunyai pengaruh yang signifikan terhadap tingkat return dari Sukuk Ritel.

Tabel 6. Perbedaan Sukuk Negara

\begin{tabular}{|c|c|c|}
\hline & Sukuk Ritel & Sukuk Tabungan \\
\hline Minimum Pemesanan & Rp. 1 Juta & Rp. 1 Juta \\
\hline Maksimum Pemesanan & Rp. 3 Miliar & Rp. 3 Miliar \\
\hline Jangka waktu & 3 tahun & 2 tahun \\
\hline Tradability & $\begin{array}{l}\text { Dapat diperjualbelikan di } \\
\text { pasar sekunder }\end{array}$ & $\begin{array}{l}\text { Tidak dapat diperjualbelikan di } \\
\text { pasar sekunder, namun terdapat } \\
\text { fasiitas early redemption (pencairan } \\
\text { sebelum jatuh tempo) }\end{array}$ \\
\hline Imbalan & $\begin{array}{l}\text { Tetap dan dibayarkan per } \\
\text { bulan }\end{array}$ & $\begin{array}{l}\text { Floating dengan minimal } \\
\text { pembayaran dan dibayarkan tiap } \\
\text { bulan }\end{array}$ \\
\hline Manfaat bagi investor & Instrumen investasi & Tabungan investasi \\
\hline
\end{tabular}
Sumber: https://www.djppr.kemenkeu.go.id/

Seiring perkembangan waktu, SR mulai dari SR001 pada 25 February 2009 dan hingga saat ini SR013, besaran imbalan/kupon Sukuk retail ini fluktuatif, pada tiap seri Sukuk Retail. Namun untuk minat masyarakat pada investasi Sukuk Retail ini meningkat dari tahun ke tahun

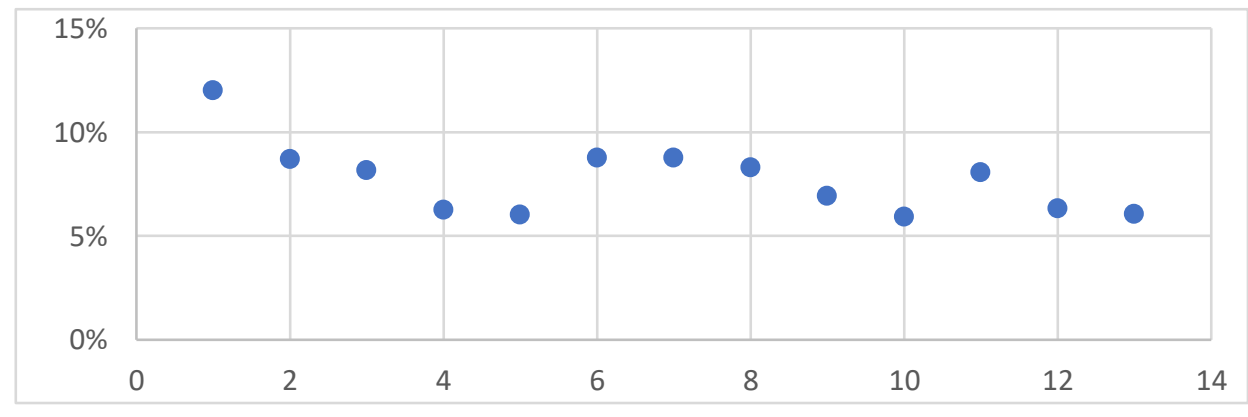

Gambar 2. Imbalan/Kupon Sukuk Retail dari SR001 sampai SR013 
Bisa dilihat dari Maturity Datenya, bahwa sejak penjualan Sukuk Negara tahun 2016. Maturity Date nya disesukan pada per tanggal 10, sesuai dengan pemberian imbalan per bulan yang dilakukan tiap tanggal 10.

Tabel 7. Sukuk Ritel Indonesia

\begin{tabular}{lllcr}
\hline & First Issue Date & \multicolumn{1}{c}{ Maturity Date } & Coupon & Outstanding \\
\hline SR001 & 25 February 2009 & 25 February 2012 & $12 \%$ & 5.556 .290 .000 .000 \\
\hline SR002 & 10 February 2010 & 10 February 2013 & $8,70 \%$ & 8.033 .860 .000 .000 \\
\hline SR003 & 23 February 2011 & 23 February 2014 & $8,15 \%$ & 7.341 .410 .000 .000 \\
\hline SR004 & 21 March 2012 & 21 September 2015 & $6,25 \%$ & 13.613 .805 .000 .000 \\
\hline SR005 & 27 February 2013 & 27 February 2016 & $6 \%$ & 14.968 .875 .000 .000 \\
\hline SR006 & 05 March 2014 & 05 March 2017 & $8,75 \%$ & 19.323 .345 .000 .000 \\
\hline SR007 & 11 March 2015 & 11 March 2018 & $8,75 \%$ & 21.965 .035 .000 .000 \\
\hline SR009 & 10 March 2016 & 10 March 2019 & $8,30 \%$ & 31.500 .000 .000 .000 \\
\hline SR010 & 21 March 2017 & 10 March 2020 & $6,90 \%$ & 14.037 .310 .000 .000 \\
\hline SR011 & 28 March 2019 & 10 March 2021 & $5,90 \%$ & 8.436 .570 .000 .000 \\
\hline SR012 & 26 March 2020 & 10 March 2022 & $8,05 \%$ & 21.117 .570 .000 .000 \\
\hline SR013 & 30 September 2020 & 10 September 2023 & $6,05 \%$ & 25.665 .971 .000 .000 \\
\hline Se
\end{tabular}

Sumber: https://www.djppr.kemenkeu.go.id/

Tabel 8. Sukuk Tabungan Indonesia

\begin{tabular}{llll}
\hline & First Issue Date & Maturity Date & Outstanding \\
\hline ST001 & 07 September 2016 & 07 January 2018 & 2.523 .913 .000 .000 \\
\hline ST002 & 29 November 2018 & 10 November 2020 & 4.907 .011 .000 .000 \\
\hline ST003 & 23 February 2019 & 10 February 2021 & 3.093 .698 .000 .000 \\
\hline ST004 & 28 May 2019 & 10 May 2021 & 2.602 .809 .000 .000 \\
\hline ST005 & 25 August 2019 & 10 August 2021 & 1.945 .098 .000 .000 \\
\hline ST006 & 28 November 2019 & 10 November 2021 & 1.459 .880 .000 .000 \\
\hline ST007 & 02 December 2020 & 10 November 2022 & 5.421 .257 .000 .000 \\
\hline
\end{tabular}

Sumber: https://www.djppr.kemenkeu.go.id/

Sukuk Ritel memberikan imbal/kupon yang fix tiap bulan. Pertaan investor muncul, bagaimana suatu investasi yang relatif sifatnya fluktuatif tapi imbalan/kuponnya bisa fix. Hal itu didasarkan pada akad investasi sukuk Retail menggunakan Ijarah/ sewa. Artinya, ketika diawal ditentukan nilai nya sebesar $8 \%$, maka imbal tersebut berlaku konstan sampai pada jatuh tempo.

Dikarenakan Sukuk Negara peruntukannya untuk pembangunan/infrastruktur, (Wilson, 2008) Penetapan harga sukuk lebih didasarkan pada variabel makroekonomi riil seperti domestik bruto produk (PDB) daripada tolok ukur bunga. Ahmad et al., (2012) dalam penelitiannya menyatakan bahwa harga sukuk dipengaruhi oleh GDP dan GDP dipengaruhi 
oleh CPI dan PPI.

Dilihat dari Tabel II, III dan IV bahwa baik SR maupun ST tidak bisa diklaim, salah satu memberikan return yang lebih besar daripada yang lainnya, jika tanpa dilakukan analisis. Nilai SR yang relatif fix, membuat investor lebih yakin untuk investasi dan membantu pembangunan negara sehingga bisa dilihat dari nilai outstanding SR yang relatif lebih besar dari ST. Jika dalam analisis fundamental dengan analisis waktu sampai jatuh tempo, negara dinilai kondisinya kurang baik/ tidak stabil maka SR menjadi pilihan investasi terbaik bagi para calon investor. Artinya, imbal jasa/kupon yang diberikan pada investor akan tetap diberikan dengan besaran yang sudah ditetapkan oleh pemerintah

Keunggulan lainya yang dimiliki SR, walaupun SR itu memiliki batas jatuh tempo 3 tahun, SR ini bisa kembali diperjualbelikan (tradability) di pasar sekunder. Jika terdapat investor lain yang bersedia membeli dengan harga lebih tinggi, dibandingkan harga diawal terbit, akan penjualan di pasar sekunder ini menciptakan peluang bagi investor Sukuk Retail uantuk mendapatkan profit lebih.

Terkait Sukuk Tabungan, imbalan/kupon yang diberikan pada investor ST sifatnya fluktuatif dengan adanya batas minimum yang ditentukan. Artinya, ketika situasi suatu negara tidak stabil yang berdampak pada menurunnya penerimaan negara, maka imbalan atas investasi ST hanya ada dibatas minimum sesuai dalam kesepakatan. Namun sebaliknya, Wilson (2008) menyampaikan bahwa saat pertumbuhan PDB tinggi penerimaan pajak pemerintah biasanya akan meningkat lebih cepat, terutama untuk negara-negara yang mayoritas pendapatannya diperoleh dari pajak penghasilan atau penjualan. Ini akan memungkinkan pemerintah untuk membayar laba yang lebih tinggi investor dalam sukuk negara.

Situasi perekonomian yang kondusif inilah menciptakan peluang bagi para investor ST untuk mendapatkan profit lebih di bulan-bulan berikutnya yang lebih besar, Walaupun ada batas jatuh tempo 2 tahun, ketika seorang investor ST menginginkan untuk menjualnya, maka penjualan bisa dilakukan pada tempat pembelian Sukuk Tabungan dilakukan (early redemption).

Bisa dibandingkan data SR8 dan ST002 kedua memperoleh imbalan yang sama $(8,3 \%)$ ketika awal pembelian Sukuk. Namun terjadi perbedaan dari Imbalan SR 008 san ST002 dikarenalan SR008 itu imbalannya tetap, artinya hingga akhir jatuh tempo sama. Sedangkan ST flutuatif, yang mana imbalan per bulan nya ada yang 8,55\%, ada juga 8,05\%.

Tapi pada dasarnya, seorang investor Sukuk Negara tidak akan mengalami kondisi Minus dalam investasinya. Pengurangan atau penambahan hanya pada imbalan/kupon yang 
dihasilkan saja, namum untuk investasi pokoknya akan kembali pada masa akhir jatuh tempo. Dan Jika dibandingkan deposito, maka Sukuk negara dinilai lebih baik, dikarenakan beban pajak yang relatif kecil.

Keputusan manusia dalam berinvestasi tidak serta merta hanya dipengaruhi oleh faktor fundamental saja, seringkali faktor yang bersifat subjektif, dijadikan dasar pengambilan keputusan investasi. Megginson (2007) menyampaikan bahwa Behavioral finance pada dasarnya adalah sebuah pendekatan komprehensif dan kohesif yang mengombinasikan analisis fundamental, teknikal, dan analisis sentimen dan psikologi dari pelaku pasar.

\section{KESIMPULAN DAN SARAN}

Sukuk Negara merupakan investasi yang semakin dikenal masyarakat Indonesia. Walaupun diawal-awal, dikenal dengan obligasi syariah. Namum seiring berkembangnya waktu, peraturan mengenai Sukuk dan SBSN sudah semakin lengkap dan bisa dipastikan Sukuk bukanlah obligasi.

Selain mendapatkan imbalan/kupon atas investasi Sukuk, selain itu masyarakat secara langsung membantu pembangunan negara melalui berbagai pembangunan infrasturktur. Beban pajak yang ditetapkan pada imbalan Sukuk (15\%) lebih rendah daripada deposito (20\%) maka jika dibandingkan dengan deposito, Sukuk dinilai lebih menjanjikan. Memang imbalan atas Sukuk relatif kecil, namun berbanding lurus dengan risiko yang dimiliki. Karena Sukuk itu pasti akan kembali modal pokoknya dan tiap bulan mendapat keuntungan.

Sukuk dinilai sesuai dengan konsep syariah. Ketika suatu investasi berbasis syariah maka penggunaan dana investasi itu hanya dilakukan pada sektor yang dinilai halal saja. Konsep ijarah yang mendasari Sukuk Ritel (SR), membuat imbalan SR tetap dari waktu ke waktu hingga masa jatuh tempo. SR bisa dijual kapanpun oleh pemiliknya di pasar sekunder tidak perlu menunggu waktu 3 tahun.

ST dengan imbalan floating with floor, besaran imbalannya bisa berubah tergantung kondisi penerimaan negara. Jika pada kondisi minimal, maka investor mendapat balas jasa dalam batas minimal dalam kesepakatan. Jika menilai bahwa situasi negara relatif kurang stabil, maka SR lebih aman dan besaran penerimaan imbalannua tetap. Namun jika kondisi negara baik dan prospektif kedepannya, maka besar kemungkinan imbalan akan naik terus menerus di tiap bulannya sehingga lebih menguntungkan.

Adapun keterbatasan dalam penelitian ini, data yang dipergunakan merupakan data sekunder dan adanya perbedaan periode penerbitan Sukuk Ritel dan Sukuk Tabungan, yang dikhawatirkan timbulnya bias. Sukuk retail terbit sejak 2009 sedangkan Sukuk Tabungan 
terbit sejak 2016. Maka untuk menyesuaikan perbedaan tersebut, penulis mempersempit data penelitian hanya di tahun terbitnya Sukuk retail dan Sukuk Tabungan bersama-sama.

Untuk peneliti selanjutnya, dapat mengkaji dengan data primer, mengenai terkait behavioral finance, terkait penanaman investasi di sektor Sukuk Negara. Apa yang memutuskan seseorang lebih memilih saham retail dibandingkan saham tabungan. Sehingga akan terlihat kompleksitas masalah Sukuk dan dapat menilai karakteristik investor Sukuk di Indonesia

\section{REFERENSI}

Ahmad, N., Daud, S. N. M., \& Kefeli, Z. (2012). Economic Forces and the Sukuk Market. Procedia - Social and Behavioral Sciences. https://doi.org/10.1016/j.sbspro.2012.11.101

Godlewski, C. J., Turk-Ariss, R., \& Weill, L. (2013). Sukuk vs. Conventional Bonds: a stock Market Perspective. Journal of Comparative Economics, 41(3), 745-761. https://doi.org/10.1016/j.jce.2013.02.006

Handayani, D., \& Surachman, E. N. (2017). Sukuk Negara as Financing Strategy for Renewable Energy Infrastructure: Case Study of Muara Laboh Geothermal Power Project. International Journal of Energy Economics and Policy.

Jensen, M. C. (1978). Market Efficiency Some Anomalous Evidence Regarding Market Efficiency I Believe There is No Other Proposition in Economics Which Has More Solid Empirical Evidence Supporting it Than the Efficient Market Hypothesis. That Hypothesis has Been Tested and w. Journal of Financial Economics, 6(July 2002), 95101.

Muhammad, R., Permana, E. N., \& Nugraheni, P. (2019). Tingkat Permintaan Sukuk Ritel: Analisis Faktor Internal dan Eksternal. Media Riset Akuntansi, Auditing \& Informasi. https://doi.org/10.25105/mraai.v19i2.4205

Megginson, W. L., \& Smart, S. B. (2009). Introduction to corporate finance.

N. Gregory, M. (2019). Principles of Economics - N. Gregory Mankiw - Google Books. https://books.google.co.id/books?id=f85kwgEACAAJ\&dq=mankiw\&sitesec=reviews

Purnamawati, I. (n.d.). Perbandingan Sukuk dan Obligasi (Telaah dari Perspektif Keuangan dan Akuntansi). Jurnal Akuntansi Universitas Jember, 62-71.

Ramasamy, R., Munisamy, S., Hanif, M., \& Helmi, M. (2011). Relative Risk Of Islamic Sukuk Over Government and Conventional Bonds. 11(6).

Sudarsono, H. (2008). Peran Obligasi Syariah (Sukuk) bagi Pembanguan Nasional. Jurnal Aplikasi Bisnis. https://doi.org/10.20885/jabis.vol7.iss12.art4

Sudaryanti, N., Mahfudz, A. A., \& Wulandari, R. (2011). Analisis Determinan Peringkat Sukuk dan Peringkat. Tazkia : Islamic Finance \& Business Review, 6(2), 105-137.

Tandelin, E. (2017). Pasar Modal: Manajemen Portofolio \& Investasi (G. Sudibyo (ed.)). PT. Kanisius.

Wafa, M. A. K. (2010). Analisa Faktor-Faktor yang Mempengaruhi Tingkat Permintaan Sukuk Ritel-I (Periode Maret 2009-Juni 2010). La_Riba. https://doi.org/10.20885/lariba.vol4.iss2.art2

Wilson, R. (2007). Islamic Bonds: Your Guide to Issuing, Structuring and Investing in Sukuk. $57,1-2$.

Wilson, R. (2008). Innovation in The Structuring of Islamic Sukuk Securities. Humanomics. https://doi.org/10.1108/08288660810899340 